\title{
Working
}

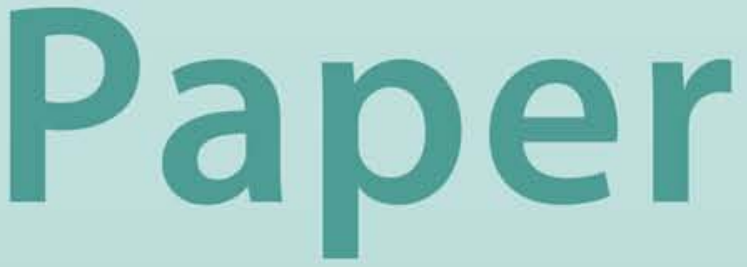




\section{Inflation Expectations and Monetary \\ Policy in India: An Empirical Exploration}

Michael Debabrata Patra and Partha Ray 


\title{
IMF Working Paper
}

Office of the Executive Director

\section{Inflation Expectations and Monetary Policy in India: An Empirical Exploration}

\author{
Prepared by Michael Debabrata Patra and Partha Ray ${ }^{1}$
}

Authorized for distribution by Arvind Virmani

\$ SUOR010

\begin{abstract}
This Working Paper should not be reported as representing the views of the IMF. The views expressed in this Working Paper are those of the author(s) and do not necessarily represent those of the IMF or IMF policy. Working Papers describe research in progress by the author(s) and are published to elicit comments and to further debate.
\end{abstract}

This paper pursues a computationally intensive approach to generate future inflation, followed by an exploration of the determinants of inflation expectations by estimating a new Keynesian type Phillips curve that takes into account country-specific characteristics, the stance of monetary and fiscal policies, marginal costs and exogenous supply shocks. The empirical results indicate that high and climbing inflation could easily seep into people's anticipation of future inflation and linger. There is a reputational bonus for monetary policy to act against inflation now rather than going for cold turkey when societal compulsions reach a critical mass.

JEL Classification Numbers:E 31, E 52

Keywords: Inflation, Inflation Expectation, India, Monetary Policy

Author’s E-Mail Address:_mpatra@imf.org ; pray@imf.org

\footnotetext{
${ }^{1}$ The authors are indented to Dr. Duvvuri Subbarao for his valuable reactions to an earlier draft of the paper. They are also grateful to Christopher Crowe, Roberto Guimaraes and Kalpana Kochhar for their comments. The views expressed in the paper are attributable to the authors only; all other usual disclaimers apply.
} 
Contents

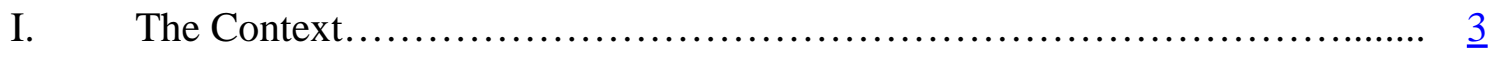

II. Recent Inflation Dynamics in India ................................. $\underline{4}$

Tracking Inflation Expectations: The State of Play $\ldots \ldots \ldots \ldots \ldots \ldots \ldots \ldots \ldots, \underline{7}$

III. Methodological Issues ........................................... $\underline{8}$

Measurement of Inflation Expectations in India: A Pragmatic Approach $\underline{\underline{9}}$

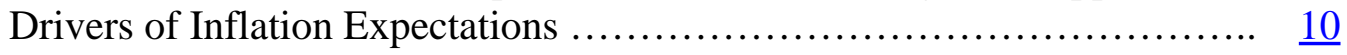

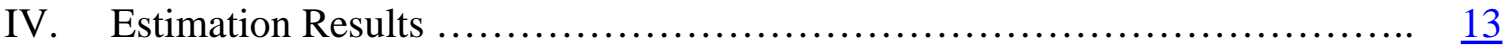

Time Series Properties of the Variables .............................. $\underline{15}$

Determinants of Inflation Expectations ............................ $\frac{16}{16}$

Is it a Cointegrating Equation? ........................................ $\underline{19}$

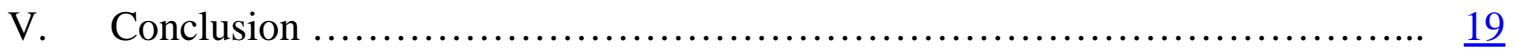

Tables

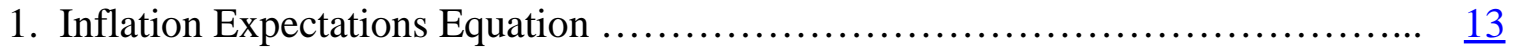

2. Descriptive Statistics of Model Performance ....................................

3. Tests for Unit Roots and Order of Integration.............................. $\frac{15}{15}$

4. Redundant Variable Test with Model-based Inflation Expectations .............. $\quad \underline{18}$

5. Redundant Variable Test with Consensus Expectations ....................... $\frac{18}{18}$

6. Results for Engle-Granger Procedure ..................................... $\frac{19}{21}$

7. Determinants of Inflationary Expectations (Model-based Forecasts) $\ldots \ldots \ldots \ldots \ldots . \underline{21}$

8. Determinants of Inflationary Expectations (based on Consensus Expectations) .... $\frac{22}{23}$

9. Cointegration LR Test Based on Maximal Eigenvalue of the Stochastic Matrix... $\underline{23}$

10. Cointegration LR Test Based on Trace of the Stochastic Matrix ................ $\quad \underline{23}$

11. Estimated Cointegrated Vectors in Johansen Estimation ....................... $\underline{24}$

Charts

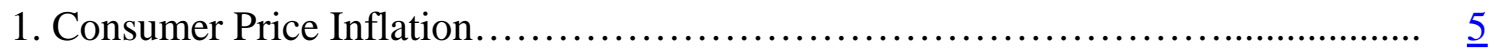

2. Movements in WPI and CPI Inflation ..................................... $\underline{6}$

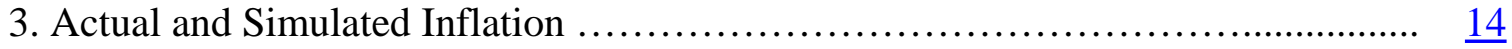

4. Consensus Inflation Forecasts and Actual (Monthly) Inflation .................. $\frac{15}{15}$

5. Impulse Response to a Change in Real Interest Rate ........................ $\underline{17}$

Annexes

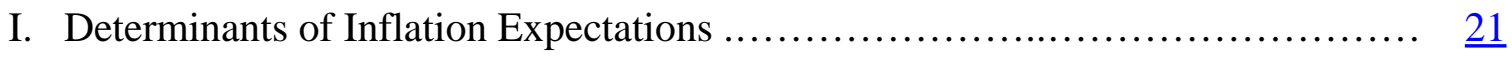

II. Cointegrating Vectors for Inflation Expectations and Determinants.............. $\underline{23}$

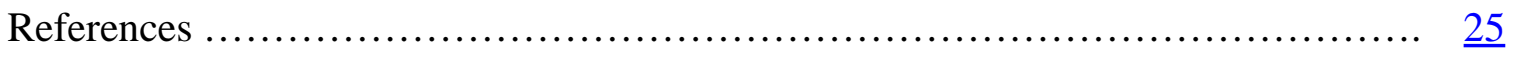




\section{The Context}

For some months now, signs of recovery from the global crisis have brightened up the horizon. The pulling out of the downturn is led by a strong rebound in Asia where various economies are perched at differing points of the cycle, with India and China set to stage a Vshaped turnaround. While the jury is still out on whether or not the worst is behind us, there is a broader consensus that the healing is likely to be sluggish and hesitant, jobless and credit constrained, at least in the initial stages. There appear to be potholes in the path to recovery. A major concern is that inflation risks are rising, especially in developing countries, and there is a real danger that monetary policy in these countries will have to be tightened sooner than later, and that growth will be stifled in its infancy.

Inflation developments are posing a daunting dilemma to monetary policy authorities across the world - 'today's most perplexing economic debate' as it has been termed (Samuelson, 2009). Headline inflation appears to be low across the world with risks of deflation persisting in some parts, and the apparent slack in economic activity is providing the rationale for continuation of highly accommodative monetary policy. At the same time, there are growing fears that the seeds of future inflation are being sown in the bed of abundant liquidity and this has formed the raison de etre for the advocacy for coordinated exit strategies from accommodation. The lesson from the past is: psychology matters. Expectations shape how economic agents behave. If they fear inflation, they act in ways that bring it about. The converse is also true, as the late 1940 s remind.

In India, perhaps more starkly than elsewhere, the dilemma is at the razor's edge. While the headline wholesale price index (WPI) inflation rose from around 1 percent in October 2009 to 9.9 percent in February 2010, consumer price index (CPI) inflation has been running in double digits on the back of high food prices for more than a year. Double-digit inflation is also showing up in the food component of the WPI. The index of food articles increased 17.8 percent in February 2010 from a year earlier. The index of primary articles prices, with a 22.03 percent weight in the wholesale price basket and comprising mainly of food items, rose 15.5 percent! Worrisome is the fact that these developments are occurring in an environment of abundant liquidity that can be traced to the policy response at the onset of the global financial crisis in September 2008 when domestic financial markets seized up in response to global developments and liquidity froze (Subbarao, 2008a, 2008b, 2009a and 2009b for a comprehensive description of the impact of the crisis on India and the policy response).

Higher food prices are a mix of structural and cyclical factors. Although inflation pressures emanating from higher food prices may limit the scope for monetary policy action, there are implications for inflation expectations if these price pressures persist. If inflation fears get embedded in expectations, sooner or later, monetary policy will have to address the dilemma. This calls for careful management of trade-offs: growth concerns warrant a delayed exit, but inflation concerns call for an earlier exit. An early exit on inflation concerns runs the risk of derailing the fragile growth, while a delayed exit may engender inflation expectations (Subbarao, 2009c). The trade-off is set to become sharper - growth has accelerated to close to 8 percent in the third quarter of 2009 while by almost a consensus, inflation is expected to rise from current lows to a similar level in early 2010, if not earlier. How and when should monetary policy react when standard indicators of inflation exert conflicting pulls? 
What do people think about inflation and what drives them to think the way they do is the theme of this paper. Although it is focused on India in view of the laboratory conditions referred to earlier, the analysis and inference has a generalized flavor that should apply as well to other emerging economies facing similar challenges. The rest of the paper is organized into four sections starting with some stylized facts about inflation dynamics in India and moving onto analytics - the measurement of inflation expectations and exploring their determinants and followed by monetary policy perspectives that can be teased out of the results obtained from modeling inflation expectations. At every stage, the paper draws heavily upon recent contributions to this strand in the literature. Concluding observations are set out in the final section.

\section{Recent Inflation Dynamics in India}

Movements in the WPI, which is akin to a producers' price index, are monitored for policy purposes as the main indicator of inflation in India. This choice, which is at variance with the international practice of assessing inflation by the CPI, is predicated on the relatively broader coverage of the WPI (447 items with a weight of 57 percent for manufactures), and its frequent and timely availability (until recently, it was released on a weekly basis as is the continuing practice with respect to its primary articles, food and fuel components; since October 2009, the headline WPI is available on a monthly basis). Releases of the WPI are keenly followed by the financial markets and yields exhibit announcement effects in anticipation of the possibility of follow-up monetary policy actions. In the period ahead, this offers rich scope for extracting market-based indicators of inflation expectations. The CPI is calculated for four different sections of society - industrial workers, urban non-manual employees and agricultural / rural laborers - distinguished by differences in average consumption baskets, and is important for indexation purposes for many wage and salary earners. Movements in the CPIs impact households as they are heavily weighted towards food (40-70 percent of the total index) and primary articles. On the other hand, the coverage and quality of the CPIs have been subject to scrutiny - illustratively, the CPI for industrial workers covers only 260 items relative to the WPI. According to India's central bank, the Reserve Bank of India (RBI), the available price indices fail to adequately capture the underlying inflationary conditions because of inadequate coverage and also because the respective base years do not capture the changed production and consumption patterns. It has underscored the need to expedite the revision of coverage and updating of the base year for the WPI series as also two proposed two consumer price indices, i.e., CPI-Urban and CPI-Rural (RBI, October 2009). The GDP deflator is the most comprehensive indicator of inflation in India but is available on an annual basis and with long lags. Measures of core and underlying inflation have been developed on the exclusion and trimmed mean principles, especially in the RBI, but the exercise has remained essentially academic and has not found favor with the public in view of its synthetic nature and the fact that food and fuel - items typically excluded from core measures - dominate the consumption basket. In recent years, primarily driven by infirmities in the indices, considerable efforts have been invested by the RBI on developing inflation expectation surveys, including for professional forecasters. These survey results, when released, promise to be an exciting vista of research and analysis for analysts and for guiding the conduct of macroeconomic policies. 
Since 2008, two distinct phases in the evolution of inflation conditions are discernible. The decline in WPI inflation in the period following its recent peak in August 2008 - when international commodity prices were soaring - coincided with the easing of global inflation, indicative of India's progressive integration of India into the global economic cycle. Year-onyear consumer price inflation in OECD countries declined from its peak of 4.9 per cent to (-) 0.3 per cent in August 2009. Amongst the major economies, headline inflation in the US, Japan and Euro Area turned negative. Core inflation also moderated in major economies along with producer price inflation, both in advanced as well as in emerging market economies (EMEs). In the emerging economies, inflation eased significantly since July 2008, in line with decreases in international commodity prices and general slowdown in economic activity brought about by the global financial crisis. Among the major emerging economies, consumer price inflation in China and Thailand turned negative in early 2009, while it turned negative in Malaysia in June 2009; other major economies also witnessed significant easing in price pressures. According to the IMF (January 2010), global inflation is expected to remain subdued on account of 'still-low levels of capacity utilization and well-anchored inflation expectations'. Inflation in advanced economies is projected to pick up from close to zero in 2009 to 1.3 per cent in 2010; on the other hand, inflation in emerging economies is expected to go up from 5.2 percent in 2009 to 6.2 percent this year. China, a few ASEAN economies and most emerging European economies are likely to experience inflation of less than 5 per cent (Chart 1).

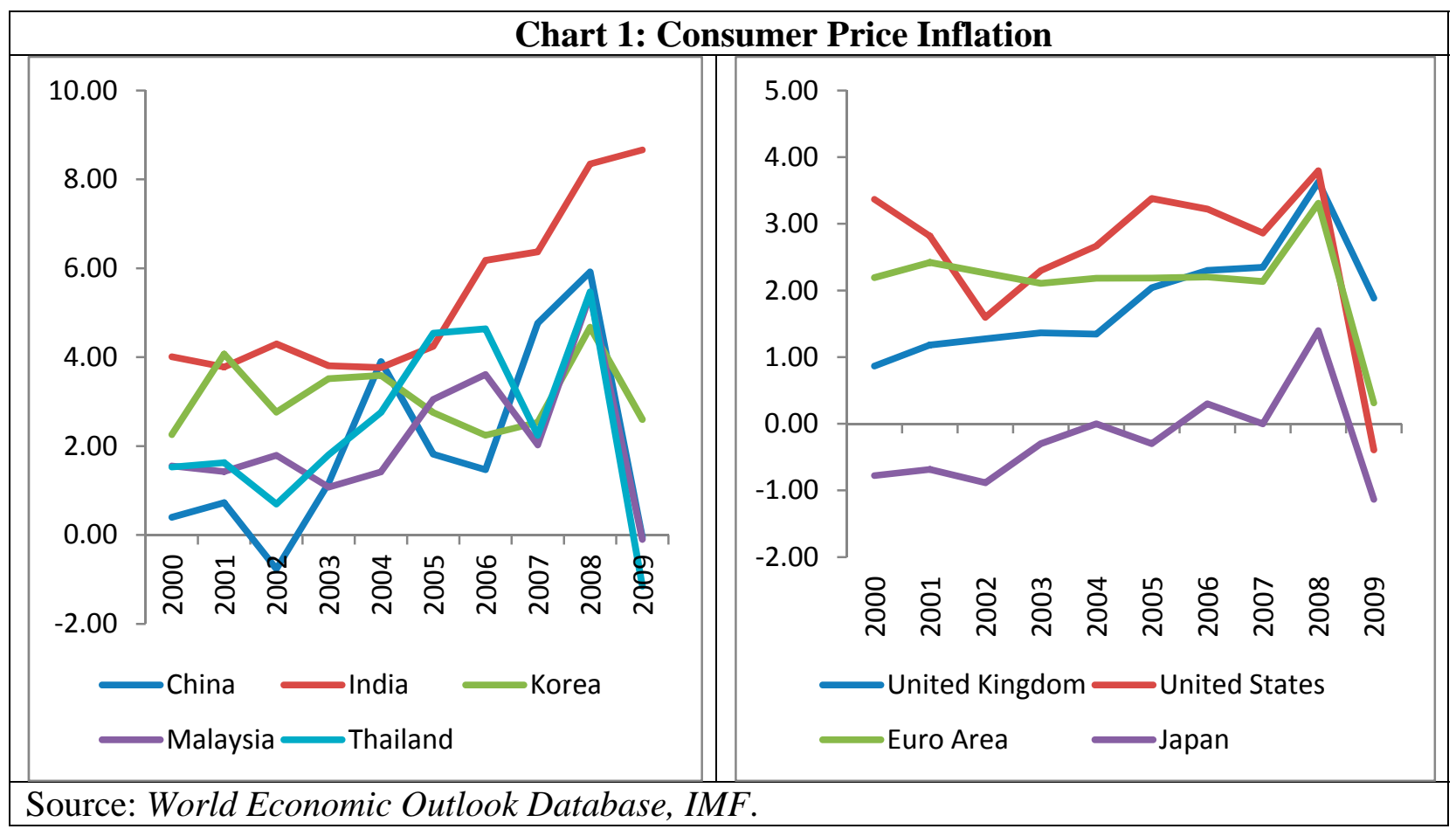

Underneath these headline indicators, inflation risks have been growing, posing a threat to the benign conditions that are being projected currently. International commodity prices declined sharply during July to December 2008, but have been firming up ahead of the nascent recovery. Prices of foodgrains such as rice, wheat and maize have been edging up, though they remain substantially below the very high levels recorded during the first half of 2008. International crude oil prices have gradually risen since March 2009 in response to expectations 
of demand strengthening as well as successive production cuts by Oil Producing and Exporting Countries (OPEC) to support prices. Crude oil prices crossed US \$ 80 per barrel on October 21, 2009 and remain elevated. Metal prices have rebounded since April 2009, led by copper, lead and nickel, mainly in response to increased demand from China.

As mentioned earlier, inflation in India measured by the WPI has tracked global inflation, plummeting from 12.9 per cent in August 2008 to 0.8 per cent by end-March 2009, slipping into negative territory for 13 consecutive weeks beginning in June 2009, before turning positive again since early September 2009. Since December, price pressures are welling up strongly. Visibly, these signs have emanated from the upward revision of administered prices of petrol and diesel (effective July 2, 2009), increase in prices of freely priced products under the fuel group in line with hardening of international crude oil prices, and higher prices of sugar, vegetables and drugs and medicines. Food articles are registering double-digit inflation, partly reflecting sharp upward revision in administratively set minimum support prices (MSP) for most of the agricultural crops, but also mirroring binding supply constraints. Vegetable prices recorded an increase of close to 20 percent on a year-on-year basis on February 6, 2010, although seasonal softening could be imminent. The increase in prices of pulses was of the order of 32 percent on March 13, 2010! Inflation based on the CPIs has increased since June 2008, mainly due to increase in the prices of food, fuel and services, and reached a range of 16.2 - 17.6 per cent during January 2010. The CPI for agricultural labourers appears to be increasing at a faster rate than the other indices. The policy response so far has been essentially supplysided: open market sale of wheat from buffer stocks; removal of restrictions such as stock holding limits in order to facilitate purchase by private traders during the harvesting season; restrictions on large consumers of sugar to conserve stock and increased releases through the public distribution system; removal of import duty on rice, wheat and raw sugar; and duty free import of white/refined sugar by Government agencies and private traders in addition to designated agencies. There is concern in India that persistently high CPI inflation could also lead to wage/cost push inflation and raise inflationary expectations (RBI, 2009).

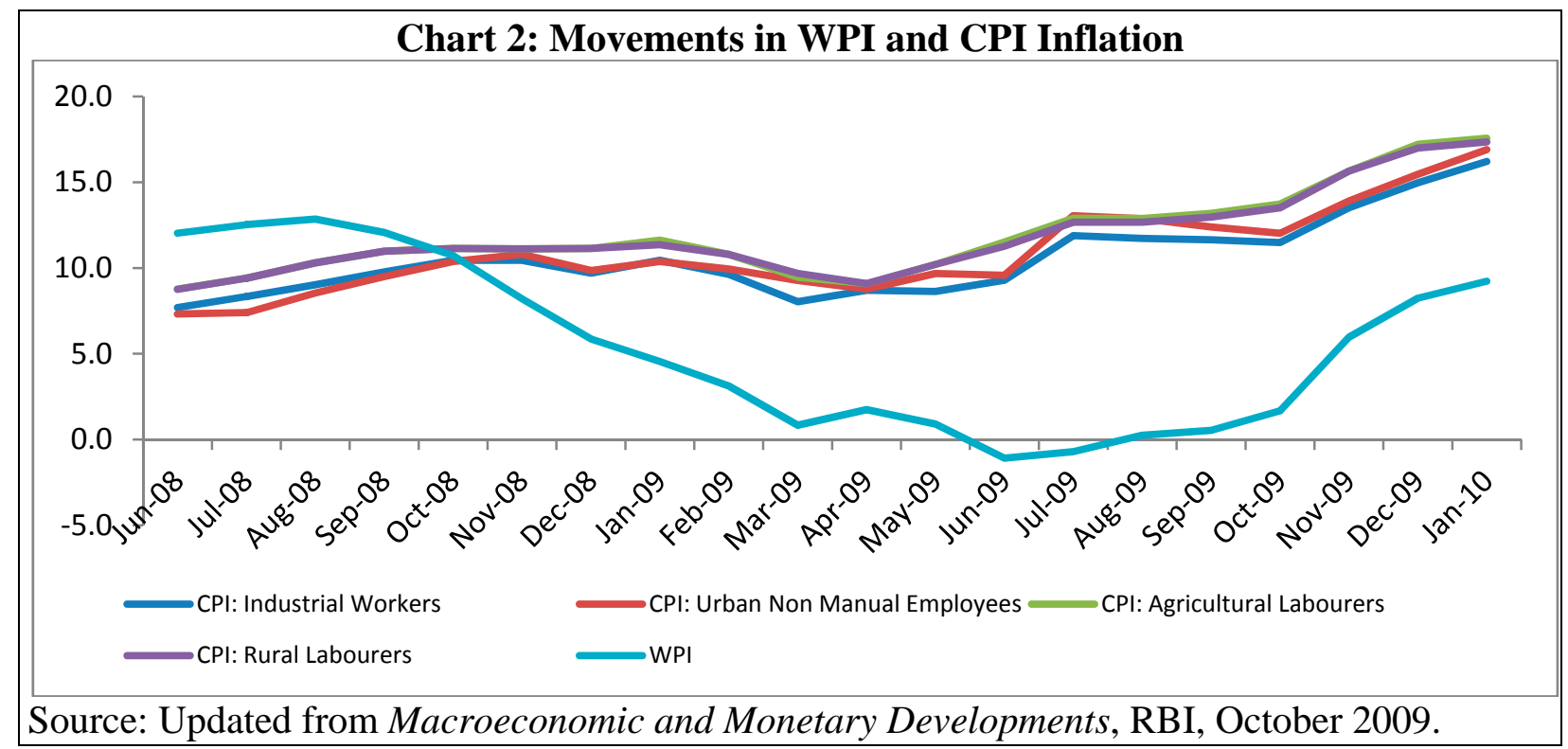


Quite clearly, the RBI is indicating discomfort with the incipient build-up of inflation. The April 2009 Annual Monetary Policy Statement (APS) of the RBI for the year 2009-10 projected WPI inflation at around 4.0 per cent by end-March 2010. The First Quarter Review of Monetary Policy issued in July 2009 noted that low/negative WPI inflation was due to statistical base effects and had not brought about a commensurate decline in inflationary expectations. Accordingly, the WPI inflation projection was upward to 5.0 per cent. In its October 2009 monetary policy statement, the RBI has indicated that base effects, which resulted in negative WPI inflation during June-August 2009, are now expected to work in the reverse direction accentuated by high food prices. The RBI's quarterly inflation expectations surveys for households indicate that a majority of the respondents expect inflation to increase over the next three months as also over the next year. Accordingly, the baseline projection for WPI inflation at end-March 2010 was projected at 6.5 per cent 'with an upside bias' as 'upside risks have materialized'. In its policy stance, it stated its preparedness 'to respond swiftly and effectively through policy adjustments to stabilize inflation expectations’ (RBI, October 2009). In its January 2010 quarterly review, the RBI indicated that upside inflation have materialized and recognized signs of demand side pressures while raising its baseline projection for WPI inflation for end-March 2010 to 8.5 per cent. More recently, on March 19, 2010 the RBI pointed out that inflationary pressures have intensified beyond its baseline projection, reflecting elevated food prices, acceleration in the prices of non-food manufactured goods, increasing capacity utilization and rising commodity and energy prices which taken together, "heighten the risks of supply-side pressures translating into a generalised inflationary process”.

\section{Tracking Inflation Expectations: The State of Play}

In India, the multiplicity of price indices and their shortcomings, and particularly, the discontent voiced by the RBI with these indicators brings forward the urgency attached to going beyond the indices and closer to what people believe is true inflation now and where it is likely to be heading in the foreseeable future that encompasses their budget and spending horizons. This is easier said than done. At the outset itself, this effort encounters formidable headwinds. The standard measures of inflation expectations are simply not available in India. There are no surveys of inflation expectations available in the public domain. Since September 2005, the RBI conducts a quarterly inflation expectations survey of households for its internal monitoring. The survey covers 4,000 households using quota sampling, across 12 cities across the four regions of the country. The survey design is purposive and the respondents are chosen so as to get a good geographical and gender representation. The survey seeks (i) qualitative responses on price changes (general prices as well as prices of specific product groups) in the next three months and the next one year and (ii) quantitative responses on current, three month ahead and one year ahead inflation rates. A Technical Advisory Committee for Surveys (TACS) was set up during the year 2007 to examine the consistency and reliability of the survey data. Its analysis revealed that the consumption pattern varies across cities. This is also reflected through the large inter-city variations in the official price indices. Confidence intervals worked out using bootstrap re-sampling plan are narrow of around 20 to 30 basis points but increase with the time horizon, indicating that the respondents are more coherent on their perception of current inflation than their expectations of the near future.

Based on these findings, an internal Group has recommended that the results of the survey may be released in the public domain in the interest of improving monetary policy 
transparency (RBI, September 2009). Even when they are available, however, it will take some time for sufficient data points to form for any meaningful analysis to be undertaken on them. Similar is the case for the RBI's survey of professional forecasters which has a purposive design and covers forecasters within the country that have an established research set-up and bring out periodic updates on economic developments - investment banks, commercial banks, stock exchanges, international brokerage houses, select educational institutions, credit rating agencies, securities firms, asset management companies, and the like. Annual as well as quarterly forecasts of major macroeconomic variables including inflation based on WPI and the CPI for industrial workers are elicited, as also probabilities attached to possible outcomes. Some salient features of the survey are provided in quarterly publications of the RBI, but again not in the nature of a consistent series that has analytical utility. The broad assessment made by the RBI's internal Group is that although " the survey is new and data is available for very few time points, GDP forecasts were closer to actual whereas the inflation forecasts were not. A better assessment of the survey results could be made in due course with a longer time series.' (RBI, September, 2009). Furthermore, break-even inflation expectations extracted from inflationindexed bonds or swaps are also not available. To the best of our knowledge, there has been only one issuance of capital-indexed bonds for which the market's appetite was listless.

\section{Methodological Issues}

Inflation expectations have for long been regarded as occupying a central role in the analysis of monetary policy and business, at least since Milton Friedman's presidential address to the American Economic Association in 1968. How much do expectations matter, what are their characteristics - whether they are adaptive or rational - , how to measure them, how quickly they respond to policy changes are some of the many facets of the intense debate that has coursed through the literature. On each of these issues, there is considerable disagreement and this has spurred the widening search for better techniques and methods of information acquisition and processing (Mankiw, Reis and Wolfers, 2003). One aspect on which there is agreement, however, is that while inflation affects purchasing power, inflation expectations are what affect people's behavior in ways that have a long-term economic impact. It is in this context and with the impetus provided by the setting of forward-looking monetary policy epitomized in the influential inflation targeting framework that has gained currency well beyond the borders of its Anglo-Saxon home - that there is wide acceptance today that one of the major objectives of modern monetary policy is to control inflation expectations. Anchoring inflation expectations is the first step to controlling inflation and minimizing the output costs of disinflation, especially in the presence of large adverse shocks.

Unfortunately, it is impossible to know exactly what people's inflation expectations are; different people have different understandings of what inflation is and what it is likely to be. What matters most are the expectations of those that directly set prices and wages - employees, companies, and the like. Nevertheless, at the cost of broad generalization, there are three main approaches to estimating inflation expectations - inflation-indexed government bonds with implied inflation expectations being the difference between the yield on an ordinary bond and the yield on an inflation-indexed bond with the same maturity; inflation swaps which provide a hedge against inflation risk which is reflected in the premium; and surveys which derive gauges of inflation expectations by asking people what they think, especially when there are perceived problems with the manner in which financial markets signal inflation ahead. Each of these 
measures has its own shortcomings which can prove to be serious impediments to empirical analysis. Market-based indicators may reflect risk premia and numerous other market factors apart from inflation expectations. Even direct economic indicators like wage settlement data may reflect not just inflation expectations but also elements such as productivity and ability to pay. Survey measures are sensitive to the particular measure of inflation - CPI, WPI, core inflation and the like. Surveys generally do not specify the specific index to which they are related and , therefore, their results have to be interpreted with caution. Several studies have also shown that survey responses exhibit high volatility (Blanchflower et al, 2009). Thus, key to the setting of forward-looking monetary policy is an adequate measure of inflation expectations. In the absence of the conventional measures the alternative to doing nothing is to adopt secondbest approaches that best approximate the formation of inflation expectations under reasonable assumptions relating to agents' behavior.

\section{Measurement of Inflation Expectations in India: A Pragmatic Approach}

Against this backdrop, a two-stage procedure is adopted here for exploring the dynamics of inflation expectations in India. First, we follow a strand in the literature that has pursued a computationally intensive approach involving unbiased and parsimonious modeling of the actual inflation process and then employing an expanding window approach to generate a time series of expectations of next period's inflation. The approach assumes rational behavior in the sense that all available information is used to assess price changes, but that in essence, money is non-neutral in the short run. For this purpose, WPI data at monthly frequency on an annualized basis are used as the aggregate prices time series after checking for stationarity properties. The time series covering the period April 1997 to December 2008 coincides with the coming into fruition of several structural reforms in the Indian economy involving external liberalization and a progressive shift towards deregulation and market orientation internally. The period also marked a shift in the monetary policy regime from one based on a broad money target towards a financial deregulation consistent multiple indicator approach in which high frequency information from financial markets is juxtaposed with output, fiscal, monetary and balance of payments developments to draw policy perspectives. Previous studies have shown that building aggregate models of inflation for this period is complicated by swings in prices of primary products, pointing to strong links between the primary sector and other areas of the economy. Furthermore, it has been found that developments in monetary aggregates still contain the 'best' information about future inflation, and that output gap specifications do not work well (Callen and Chang, 1999). We examine these findings too in the context of our work which incorporates more recent information at relatively high frequency (monthly as against quarterly/annual data in earlier studies).

Drawing from the properties of the data as explained in the following section, the monthly inflation series is modeled in an autoregressive moving average (ARMA) framework in which the data are expressed in terms of past values (the AR component) and current and lagged values of a white noise term (the MA component) i.e., recent and past values of the forecast error. Seasonal AR and MA terms are also used in view of the seasonality properties detected through the X12 algorithm and confirmed by other diagnostics, as shown subsequently. As is well known, the ARMA representation provides a univariate model, specifying the conditional mean of the series as a constant, and measuring the residuals as differences of the series from its mean. The ARMA specification was chosen following several exploratory alternative 
formulations seeking goodness of fit. The ARMA method is essentially agnostic and does not assume knowledge of any underlying driver or structural relationship. We find this useful, being conscious that we are not following the standard processes of measuring inflation expectations for reasons stated earlier, and forecasts generated by the modeling should be as unbiased as possible to be truly representative of people's rational expectations of the future. Undoubtedly, there are disadvantages - subjectivity of model identification; and that it not embedded within any underlying theoretical or structural prior. Furthermore, ARMA representations could be poor at predicting turning points. Nevertheless, ARMA models have proven to be robust in generating short-term inflation forecasts, which is a key consideration for the theme of this paper, and have been found to outperform more sophisticated structural models (Stockton and Glassman, 1987; Litterman, 1986; Meyler et al, 1998).

Given the annual monthly frequency of the data, the best fit for the inflation process is captured in terms of

$$
\text { (1) } \pi_{t}^{e}=f[A R(p), M A(q), S A R(m), S M A(n)]
$$

where $\mathrm{p}, \mathrm{q}, \mathrm{m}$ and $\mathrm{n}$ represent respectively the order of the AR, MA, SAR and SMA terms, and SAR and SMA represent seasonal terms as explained earlier. ${ }^{2}$ Employing (1), one period ahead unbiased forecasts of inflation are obtained to represent inflation expectations. This is accomplished by generating a covariance stationary series.

We are conscious that a model-based approach to generating inflation expectations is open to the criticism that they are essentially forecasts obtained from modeling actual inflation. As mentioned earlier, this is a pragmatic approach of the second best that we are constrained to adopt in the absence of the standard measures of inflation expectations, but in recognition of the stated objective of the RBI of anchoring inflation expectations in the conduct of monetary policy. Furthermore, it draws from a precedent tradition in the literature (Meyler, Kenny and Quin, 1998; McCulloch and Stec, 2000; Juntilla, 2001. Be that as it may, for the purpose of comparison and verification of our results, we extracted inflation expectations reported on a monthly basis to Consensus Economics through surveys covering financial entities such as banks, fund managers and financial firms (hereafter referred to as consensus expectations). The reportings are not systematic or uniform and samples vary from month to month. Moreover, these reports are provided on an individual entity basis so that a single number for a particular month can be obtained only by averaging with due consideration to the month ahead to which these forecasts pertain.

\section{Drivers of Inflation Expectations}

After obtaining a quantifiable series of inflation expectations for the period of study, the next stage is to assess the formation of these expectations and also the role of inflation

\footnotetext{
${ }^{2}$ Essentially, price-setting behavior is observed as a continuous process of updating the new price based on the most recently observed inflation rate. Thus, the average newly set price can be seen as a combination of prices posted by backward-looking and forward-looking price setters (Celasun, Gelos, and Prati, 2004; Galí and Gertler, 1999; Cerisola and Gelos, 2005; Pinin, Gelos and Lopez-Mejia, 2008).
} 
expectations in shaping the inflation process. If inflation expectations have an important role in driving the inflation process in India, anchoring expectations is important for monetary policy. Drawing from reasonably robust empirical verification in the Indian context (RBI, 2002; Kapur and Patra, 2003) and in the tradition of Celasun et al (2004) and Gelos and Iriondo (2008), we estimate a new Keynesian type Phillips curve assuming rational behavior on the part of the agents but that markets do not clear, i.e., prices are sticky. The procedure essentially involves estimating a reduced-form equation to assess the role of the fundamental determinants and changes in underlying dynamics. The scarce literature exploring empirically the determinants of inflation expectations in emerging market economies has either focused on target credibility (Minella et al., 2003; Celasun et al, 2004), or, more recently on the role of fiscal expectations (Celasun, Gelos, and Prati, 2004a and 2004b). In India, monetary policy does not set explicit inflation targets, but there is implicit recognition of the existence of a social tolerance threshold for inflation. The model estimated here takes into account country-specific characteristics such as past inflation for assessing persistence or inertia, the output gap embodying aggregate demand and measured as deviations of actual GDP from its trend ${ }^{3}$, growth in real government expenditure as a measure of the fiscal stance, the real interest rate as an embodiment of the monetary policy stance, the changes in the real effective exchange rate as a proxy for marginal costs and prices of food and fuel to capture the exogenous shocks to which the Indian economy is frequently subjected to and which have a determining influence on the inflation formation process. In essence, the presence of the output gap, the policy stance variables, and proxies for marginal costs and exogenous shocks serves as conditioning variables to help isolate the degree of persistence.

For the purpose of identifying the determinants and the underlying lag structures that characterize the process of formation of inflation expectations, we employ Hendry's general to specific approach (popularly referred to as the London School of Economics or LSE approach) which mimics the theory of reduction to obtain the final econometric model. The theory of reduction and the general-to-specific approach underlying the LSE methodology yields an empiricist procedure in which econometric models match the actual phenomena in most of the measurable respects (Chao, 2001; Campos et al, 2004). The idea of a general to specific model is fairly intuitive. Instead of artificially imposing any lag structure on any model, it starts from a general dynamic statistical model, which captures the essential characteristics of the underlying data set. Standard statistical testing procedures are then used to reduce its complexity by eliminating statistically insignificant variables and to check the validity of the reductions in order to ensure the congruency of the model. As the reduction process is inherently iterative, many reduction paths can be considered, which may lead to different terminal specifications. 'Encompassing' is then used to test between these, usually non-nested, specifications, and only

\footnotetext{
${ }^{3}$ E-Views provides a quadratic interpolation method whereby local quadratic functions are run on the quarterly data so that the sum of the interpolated data matches to the source data. The quadratic polynomial is formed by taking sets of three adjacent points from the source series and fitting a quadratic so that the sum of the high frequency points matches the low frequency data actually observed. For most points, one point before and one point after the period currently being interpolated are used to provide the three points. For end points, the two periods are both taken from the one side where data is available. The resulting interpolation curves are not constrained to be continuous at the boundaries between adjacent periods.
} 
models which survive the encompassing step are kept for further consideration. If more than one model survives this "testimation" process, it becomes the new general model, and the specification process is re-applied to it. General to specific modeling is seen to be superior to assumed relations. Illustratively, in Monte Carlo experiments, the general-to-specific approach was successful in recovering the specification of the data generating process (DGP) with a remarkable accuracy (Krolzig, 1999).

Thus, the estimated equation takes the following form:

(2) $\pi_{t}^{e}=f\left[\sum_{i} \pi_{t-i}, \sum_{i}\left(y_{t-i}-y^{*}\right), \sum_{i} g(E X P N)_{t-i}, \sum_{i} g(R E E R)_{t-i}, \sum_{i} \pi_{t-i}^{P R}, \sum_{i} \pi_{t-i}^{F L}\right]$

where $\pi_{\mathrm{t}-\mathrm{i}}$ is lagged inflation; $\left(\mathrm{y}-\mathrm{y}^{*}\right)$ is the output gap defined as actual GDP minus trend GDP ( also see Annex 1), g(EXPN) is the growth of real expenditures of the central Government, $\mathrm{g}(\mathrm{REER})$ is the annualized monthly change in the REER in percent and $\pi^{\mathrm{FL}}$ and $\pi^{\mathrm{PR}}$ are the percentage changes in prices of fuel and primary products, respectively. The subscripts indicate summing over various lags. Seasonal adjustments were not undertaken as they could transform the time series properties of the data.

The exercise was repeated using forecasts extracted from consensus forecasts, as stated earlier, to cross-check our preferred equation. It is necessary to mention that alternate variables to capture the monetary policy stance such as real money gap, growth in money supply and changes in the nominal effective exchange rate were used but were insignificant and are, therefore, not reported here. The estimation results are discussed in the following section.

At this point, a brief digression to the animated empirical debate on the new Keynesian Phillips curve as a connect between inflation expectations and monetary policy might be worthwhile. In the years following the original specification of the Phillips curve in 1958, the dominant paradigm was adaptive expectations. This was until the idea entered that agents form expectations optimally, given their understanding of the economy and information available to them - rational expectations (Lucas, 1970) - a view attributable to the hypothesis that 'expectations are....essentially the same as predictions of the relevant economic theory' (Muth, 1961). In subsequent empirical work, it emerged that price adjustments are inherently sluggish, reflecting nominal rigidities (Taylor, 1980; Rotemberg, 1982; Calvo, 1983) and imperfect information, including regarding the central bank's actions. Even Lucas had indicated that expectations were rational subject to an information constraint. Beginning in the 1980s, there is now a large body of work that documents the general failure of the rational expectations hypothesis in accounting for inflation expectations formation [Batchelor and Dua (1987), Pacquet (1992) and Blanchflower et al (2009) provide an assessment of the empirical evidence; Millet (2007) terms the rational expectations concept as empirically bankrupt:"theory dependence can easily be as dangerous as data dependence"]. One widely cited explanation is that agents such as households and even firms lack the sophistication to form expectations rationally. The presence of information costs and asymmetries is another major factor. Most surveys are characterised by high non-response rates. Many respondents have no idea what the inflation rate will be in the future. Also, expectations are widely found to be backward-looking and it is a fact that individuals' perception of current inflation is a highly significant determinant of their inflation expectations. 
Models of imperfect information and its effects on inflation expectations have proliferated in the literature. These models provided a plausible explanation of inflation dynamics and could explain many of the stylized facts regarding prominent inflation episodes (see Kiley, 2009 for a comprehensive recent review). An influential development has been models that combine sticky prices and sticky information (Woodford, 2008). The new Keynesian Phillips curve captures the essence of this dynamic - that sticky prices somehow result in forward-looking behavior, and current inflation is determined by inflation expectations, the pressure of demand, current and anticipated, and other marginal costs. This has been widely used in the analysis of monetary policy - "the closest thing there is to a standard specification" (McCallum, 1997). Recent contributions have offered evidence in favour of the new Keynesian Phillips curve (Gail and Gertler, 1999; Brissimis and Magginas, 2008) and several studies have shown that traditional backward-looking price setting rules appear to be preferable to the forward-looking alternatives (Rudd and Whelan, 2005 review this body of work).

\section{Estimation Results}

The objective of generating unbiased one period ahead forecasts of inflation to serve as proxies for inflation expectations is also the driver of the search for a parsimonious model for the data. A correlogram indicates a 'wavy' cyclical pattern with a seasonal frequency, with the autocorrelations becoming zero after one lag and the partial autocorrelations declining geometrically. The Akaike Information Criterion and the Schwarz-Bayesian Criterion read together suggest a lag order of 1 i.e., that an ARMA $(1,1)$ is appropriate. Furthermore, in view of the monthly frequency of the data and visual evidence of systematic seasonal movements, inclusion of both seasonal AR and MA terms each of order 12 is warranted (Box and Jenkins, 1970). All data are taken from the IMF's database provided by the CEIC Data Company Ltd.

Table 1: Inflation Expectations Equation

\begin{tabular}{|l|r|r|r|r|}
\hline \multicolumn{1}{|c|}{ Variable } & Coefficient & Std. Error & t-Statistic & Prob. \\
\hline C & 0.0509 & 0.0025 & 20.3436 & 0.0000 \\
\hline AR(1) & 0.9100 & 0.0429 & 21.2210 & 0.0000 \\
\hline SAR(12) & -0.2284 & 0.1153 & -1.9807 & 0.0501 \\
\hline MA(2) & 0.3212 & 0.1023 & 3.1405 & 0.0022 \\
\hline SMA(12) & -0.8406 & 0.0310 & -27.0923 & 0.0000 \\
\hline R-squared & 0.9285 & \multicolumn{2}{|l|}{ Mean dependent var } & 0.0530 \\
\hline Adjusted R-squared & 0.9260 & S.D. dependent var & 0.0224 \\
\hline S.E. of regression & 0.0061 & Akaike info criterion & -7.3171 \\
\hline Sum squared resid & 0.0041 & \multicolumn{2}{l|}{ Schwarz criterion } & -7.1984 \\
\hline Log likelihood & 429.3937 & \multicolumn{2}{l|}{ Hannan-Quinn criter. } & -7.2690 \\
\hline F-statistic & $360.5060(0.00)$ & \multicolumn{2}{l|}{ Durbin-Watson stat } & 1.2447 \\
\hline
\end{tabular}

The estimated equation appears well determined in terms of the diagnostics (Table 1) and the graph showing the actual and simulated data (PI and FORECASTPI, respectively, in Chart 3) shows that the turning points are reasonably well captured, attesting to the choice of the model. 


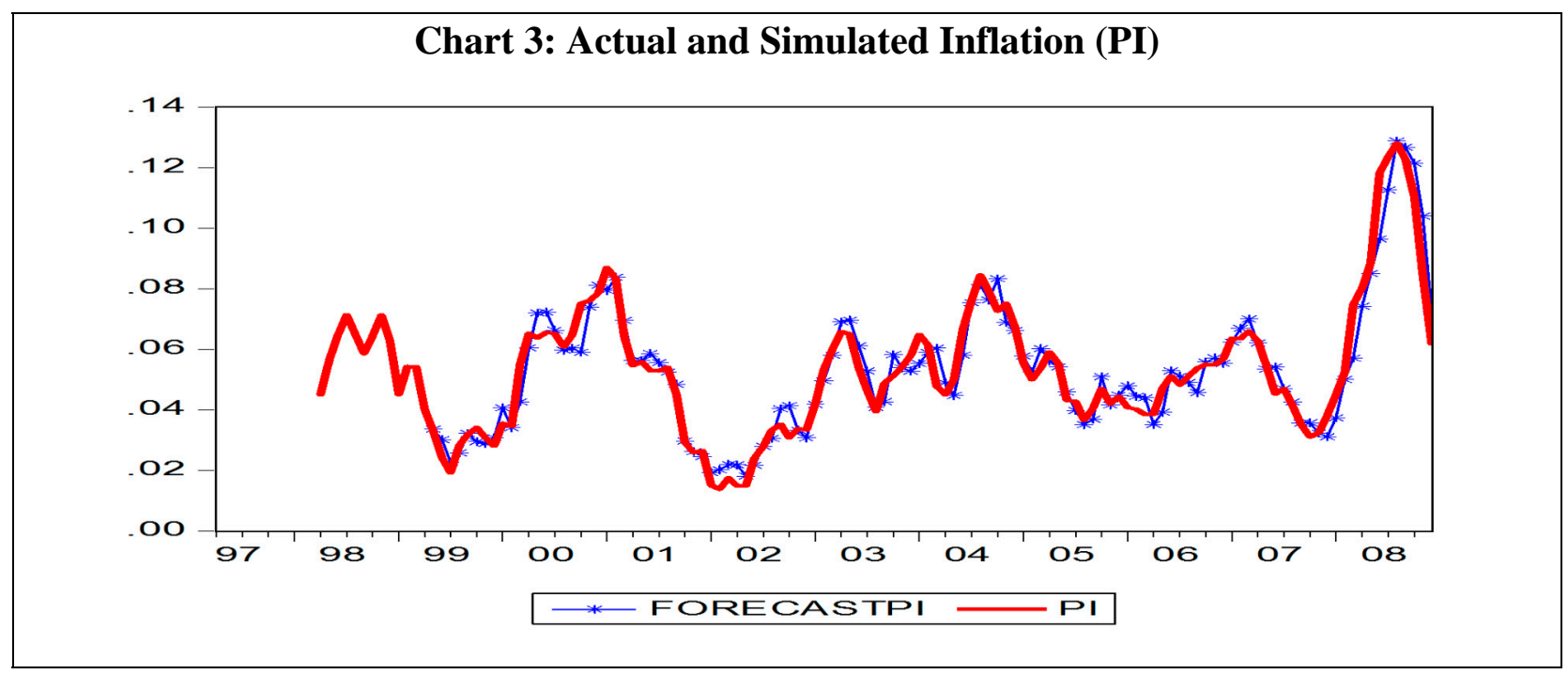

The model yields the following equation for forecasting purposes so as to generate next period (month) inflation expectations:

$$
\pi^{\mathrm{e}}=0.006+0.91 \pi_{\mathrm{t}-1}-0.22 \pi_{\mathrm{t}-12}+0.20 \pi_{\mathrm{t}-13}+\varepsilon_{\mathrm{t}}+0.32 \varepsilon_{\mathrm{t}-2}-0.85 \varepsilon_{\mathrm{t}-12}-0.27 \varepsilon_{\mathrm{t}-14}
$$

Table 2: Descriptive Statistics of Model Performance

\begin{tabular}{|l|l|}
\hline Statistic & Value \\
\hline Root Mean Squared Error & 0.005972 \\
\hline Mean Absolute Error & 0.004394 \\
\hline Mean Abs. Percent Error & 9.244995 \\
\hline Theil Inequality Coefficient & 0.051917 \\
\hline \multicolumn{1}{|c|}{ Bias Proportion } & 0.001089 \\
\hline Variance Proportion & 0.009193 \\
\hline Covariance Proportion & 0.989718 \\
\hline
\end{tabular}

By contrast, inflation expectations obtained from forecasts of financial entities reported to Consensus Economics (PIECONSENSUS in Chart 4) appear to average out fluctuations and set a middle path through the actual (PI) turning points as shown below. In all fairness, it needs to be mentioned that these forecasts that have been assumed to represent inflation expectations of polled financial market participants suffer from several infirmities mentioned earlier such as unequal reporting samples, disparate responses to anticipated monetary policy responses depending on the position taken on the yield curve, asymmetric information availability that dominates Indian financial markets and a rough averaging across doves (monetary policy will not react) and hawks (monetary policy will react) with money to be made in between. In time and with the development of more systematic processes of information gathering and data processing, this can be an extremely fertile ground for the harvesting of informed inflation expectations. 


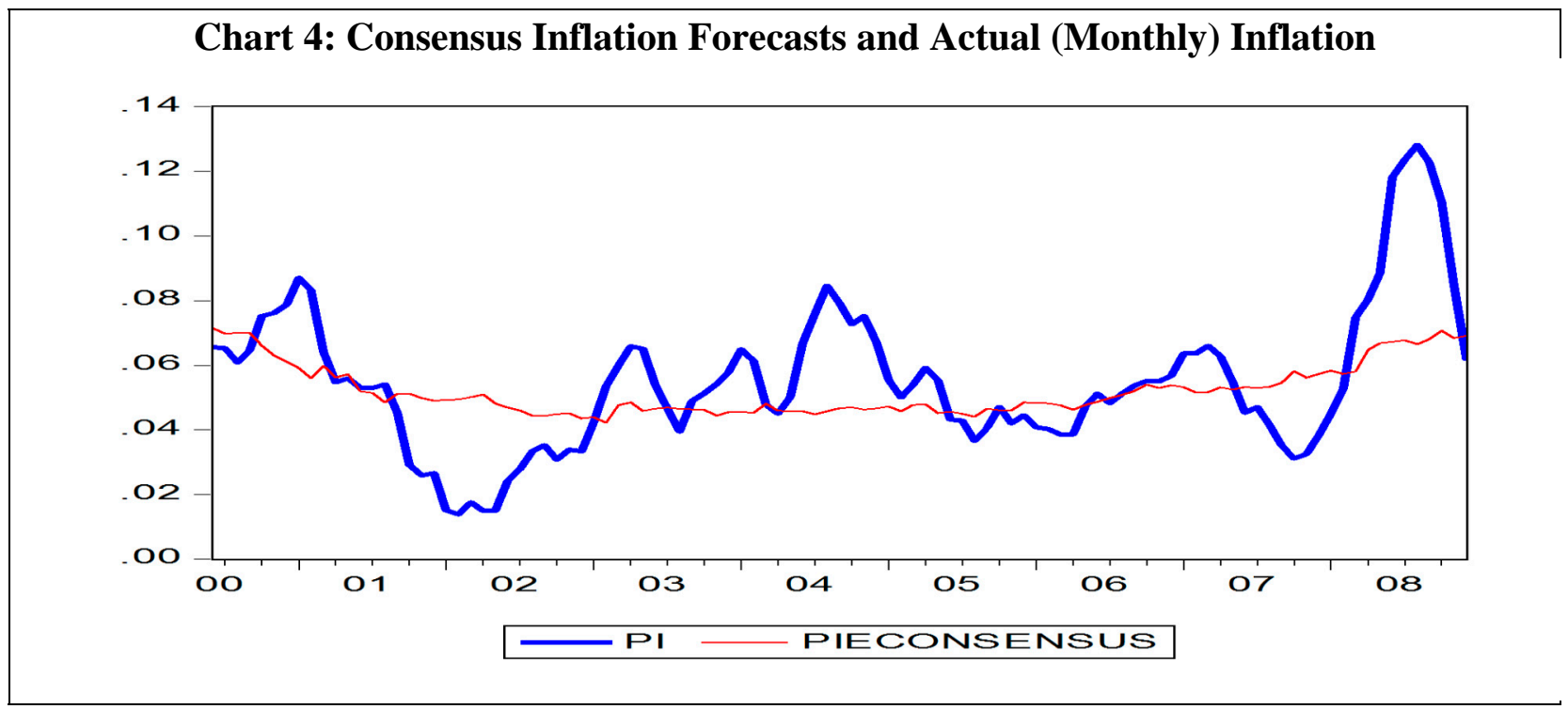

We now turn to the crucial question from the policy point of view: What factors drive inflation expectations in India?

\section{Time Series Properties of the Variables}

Previous studies employing monthly inflation (annualized) data allude to the possibility of dealing with a trending series and that the trend could be time-varying (McCulloch et al, 2000). Accordingly, the possibility that monthly inflation could be a non-stationary process, at most an I(1) series, cannot be ruled out. A popular approach in this context is to model the series by using first differenced data. There are, however, two shortcomings involved. First, it has been argued that the presence of a unit root or otherwise in a finite sample is inherently unanswerable (Stock, 1990; Cochrane, 1991) - that standard unit root tests do not have the power to distinguish between a series with a unit root and one with a near unit root. Second, differencing inevitably leads to loss of information and if the assumption of a unit root is untrue, over-differencing can lead to inefficient parameter estimates.

Augmented Dickey-Fuller (ADF) ' $\mathrm{t}$ ' and Philips-Perron (PP) ' $\mathrm{Z}$ ' tests presented below indicate that all the variables, except changes in the real effective exchange rate, appear to be unambiguously I(0). Notwithstanding the ambivalence relating to the real exchange rate, we incorporate it in the estimation in view of the economic prior referred to earlier.

Table 3: Tests for Unit Roots and Order of Integration

\begin{tabular}{|l|c|c|}
\hline Variable & ADF & PP \\
\hline Inflation (\%) & $-3.3724^{* *}$ & $-2.5810^{* * *}$ \\
\hline Output Gap (\%) & $-4.2507^{*}$ & $-3.6500^{*}$ \\
\hline Real Interest Rate (\%) & $-8.2045^{*}$ & $-8.2446^{*}$ \\
\hline Real Fiscal Expenditure Growth(\%) & $-9.7058^{*}$ & $-9.7057^{*}$ \\
\hline Real Effective Exchange Rate (\% Change) & -2.2100 & -1.7352 \\
\hline Primary Article Prices (\% change) & $-3.1398^{* * *}$ & $-2.8797^{* * *}$ \\
\hline Fuel Prices (\% change) & $-3.7235^{*}$ & $-4.0767^{*}$ \\
\hline
\end{tabular}

$* 1 \%$ level of significance; ** $5 \%$ level of significance; *** $10 \%$ level of significance; 


\section{Determinants of Inflation Expectations}

In general, the estimation results are robust and track inflation expectations reasonably well. Lagged inflation, changes in fuel and primary articles prices and the output gap are the main determinants, followed by the real interest rate (Table A1 in Annex I).

The estimates suggest that the sum of the coefficients on lagged inflation (one month and twelve-month, in particular) contributes nearly 50 percent to explaining the formation of inflation expectations. This is indicative of a high degree of inertia or persistence. ${ }^{4}$

Changes in prices of primary articles account for a little under a third of expected inflation, reflecting the importance of food prices, in particular, to people in anticipating future inflation. Taken together, food and fuel price changes account for 40 percent of variations in inflation expectations. This highlights the importance of these items in the average consumption basket of large sections of the Indian population, administered elements of price-setting and their potential role in imparting inertia. Issues relating to dependence on international prices, the degree of pass-through and thereby imported inflation accordingly assume relevance within their backward-looking behavior. The continuing role of food and fuel prices in influencing inflation expectations points to the abiding vulnerability to exogenous supply shocks, either imported or domestically driven.

As expected, the output gap enters with a positive sign and is significant, accounting close to 14 percent of expected inflation and vindicating our choice of a new Keynesian framework to explain the process of formation of inflation expectation in India. ${ }^{5}$ For developing countries, inflation is often driven by excess demand pressures and this, in turn, supports our inference relating to the role of macroeconomic policies in stabilizing expectations. The finding that the output gap is statistically significant with one-period lag, indicates the speed at which aggregate demand can translate into inflationary pressures in people's expectations which, in turn, highlights the importance of appropriate timing in the policy response.

An important finding from the point of view of the subject of this paper is the influence of the real interest rate which proxies the stance of monetary policy. In contrast to earlier studies which found that monetary aggregates appeared to contain the best information about future inflation - in fact, the information content of the monetary aggregates was found to have improved after financial deregulation (Callen et al, 1999) - our experience with using monetary aggregates, including growth rates and real and nominal money gaps, was unsatisfactory. On the other hand, the significant and negatively signed coefficient on the real interest rate that we obtain is consistent with the impact of financial sector reforms since the mid-1990s. The deregulation of interest rates and a growing outward and market orientation has brought with it instrument independence for monetary policy and a greater role in pegging inflation in a forward-looking sense. Monetary policy regime changes since the late 1990s de-emphasized the role of monetary aggregates and ushered in an increasing reliance on indirect instruments of monetary policy leading to the importance of the rate channel relative to the quantity channel in impacting future inflation. The negative sign on the coefficient on real interest rates attests to

\footnotetext{
${ }^{4}$ This is also borne out by the almost identical size of the coefficient obtained from estimates from consensus inflation expectations (Annex III).

${ }^{5}$ Estimates from consensus expectations yield a coefficient of similar size but with a perverse sign.
} 
the credibility earned by monetary policy in anchoring inflation expectations in recent years - a rise in interest rates signals lower inflation expectations in the period ahead. In this context, the significance of the 12-month lagged real interest rate and relatively low coefficient is indicative of the time taken for monetary policy actions to feed through into expectations. These results are strongly supported by the estimates obtained from modeling consensus expectations which yield negatively signed coefficient on the real interest rate of near-identical magnitude.

An important issue in the context of a developing country is the need to consider the impact of monetary policy action on growth alongside inflation, given the powerful and lasting effects of monetary policy on output that has been documented in the literature (Blanchard, 1990). While the appropriate approach would be to estimate a full structural model, we estimated a vector autoregression model (with the same variables) to assess the strength of the impulse response of the output gap and inflation expectations to changes in the real interest rate. We found that inflation expectations fall below initial conditions persistently over a period of nearly a year whereas the decline in the output gap is almost negligible and occurs weakly between 8-12 months (Chart 5).

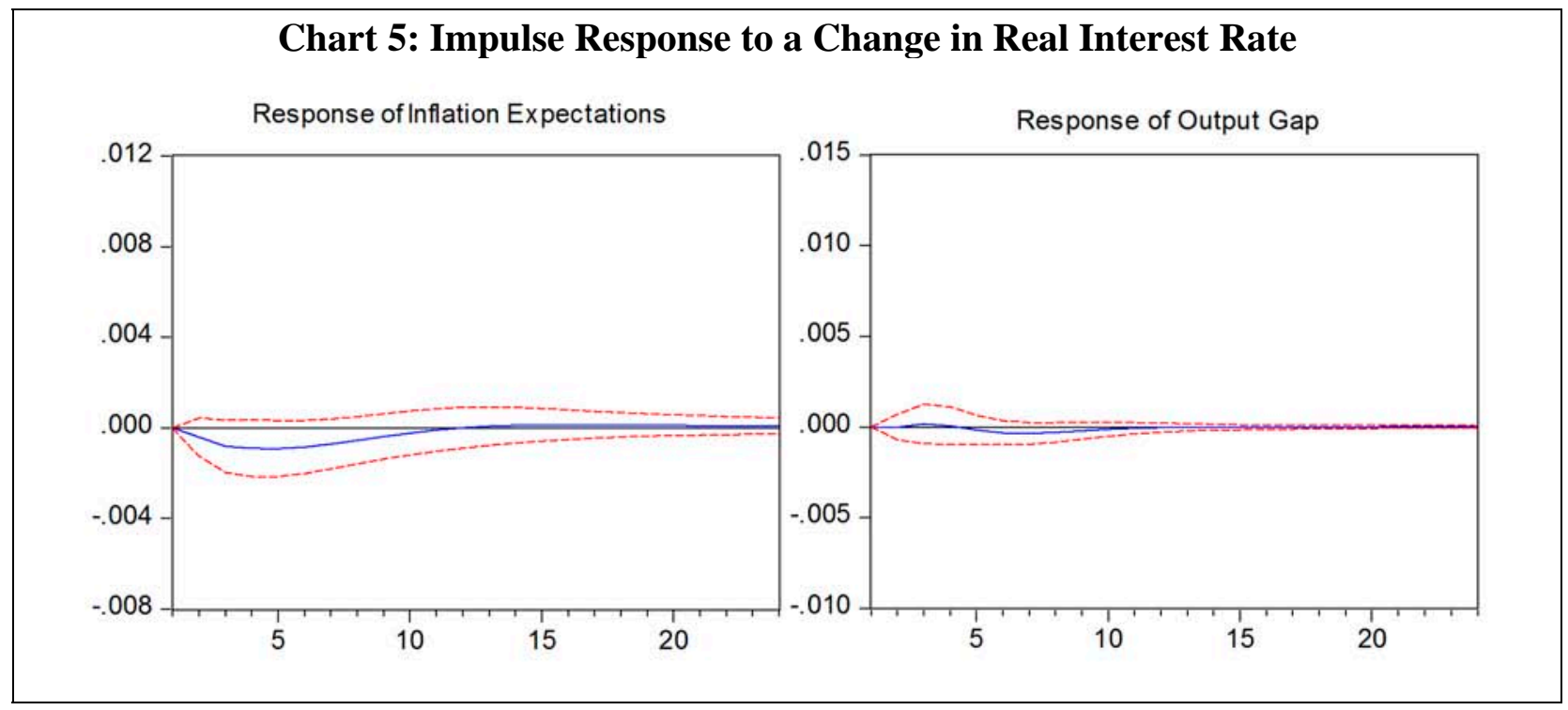

The proxy for marginal costs also enters the estimation significantly and with the expected negative sign. An appreciation in the real exchange rate is expected to lower inflationary pressures and thereby bring down inflation expectations. The negative sign also indicates that agents view changes in the REER as transitory deviations from some notion of the equilibrium path and expect it to revert in the period ahead. As expected in an economy that mainly relies on domestic demand, the coefficient on the real exchange rate is low, indicating also a muted and lagged pass-through to domestic inflation, relative to other emerging market economies. Nevertheless, it provides sufficient justification for the exchange rate to enter as an argument in the monetary policy reaction function, albeit with a lower weight than the variables discussed in the preceding paragraphs.

Contrary to finding in other studies (Cerisola et al and Gelos et al), the role of fiscal policy in shaping inflation expectations is marginal and surprisingly has a negative sign - an 
acceleration in real expenditure lowers inflation expectations. ${ }^{6}$ This is counter-intuitive for a country in which fiscal policy has traditionally been ascribed inflationary consequences. This has to be viewed, however, in conjunction with developments characterizing the period in which this paper is set. First, this was a period in which fiscal responsibility legislation was enacted and a measure of consolidation was achieved; accordingly, a rise in expenditure would be expected to be offset by corresponding increases in taxes or other revenues and therefore lower inflation expectations. Furthermore, during this period, fiscal rectitude was also accompanied by the prudent, and even hawkish, conduct of monetary policy. This would signal in people's expectations strong monetary policy responses to increases in fiscal spending in line with the progressive independence from fiscal dominance.

Detailed estimation results for model-based inflation expectations and for consensus expectation are given in Annex 1. Since each variable enters with multiple lags, a more meaningful representation of the model could be in terms of sums of coefficients along with tests for redundancy These results, which are presented in Tables 4 and 5, indicate that all variables are relevant along with their lags. This is, however, to be expected in a Hendry-type general to specific framework where the robust model is thrown up by a battery of diagnostics.

Table 4: Redundant Variable Test with Model-based Inflation Expectations

\begin{tabular}{|l|r|l|l|}
\hline Variable & Sum of Coeffts & Redundant Variable Test \\
\cline { 3 - 4 } & & F-Stat & p-values \\
\hline Lagged Inflation & 0.4609 & 42.89 & 0.00 \\
\hline GDPGAP & 0.1381 & 22.04 & 0.00 \\
\hline g(EXPN) & -0.0020 & 6.16 & 0.00 \\
\hline g(REER) & -0.0293 & 7.17 & 0.00 \\
\hline Real Interest Rate & -0.0611 & 2.32 & 0.05 \\
\hline Primary Articles' Prices Inflation & 0.2903 & 39.11 & 0.00 \\
\hline Fuel Prices Inflation & 0.1057 & 43.32 & 0.00 \\
\hline
\end{tabular}

Table 5: Redundant Variable Test with Consensus Expectations

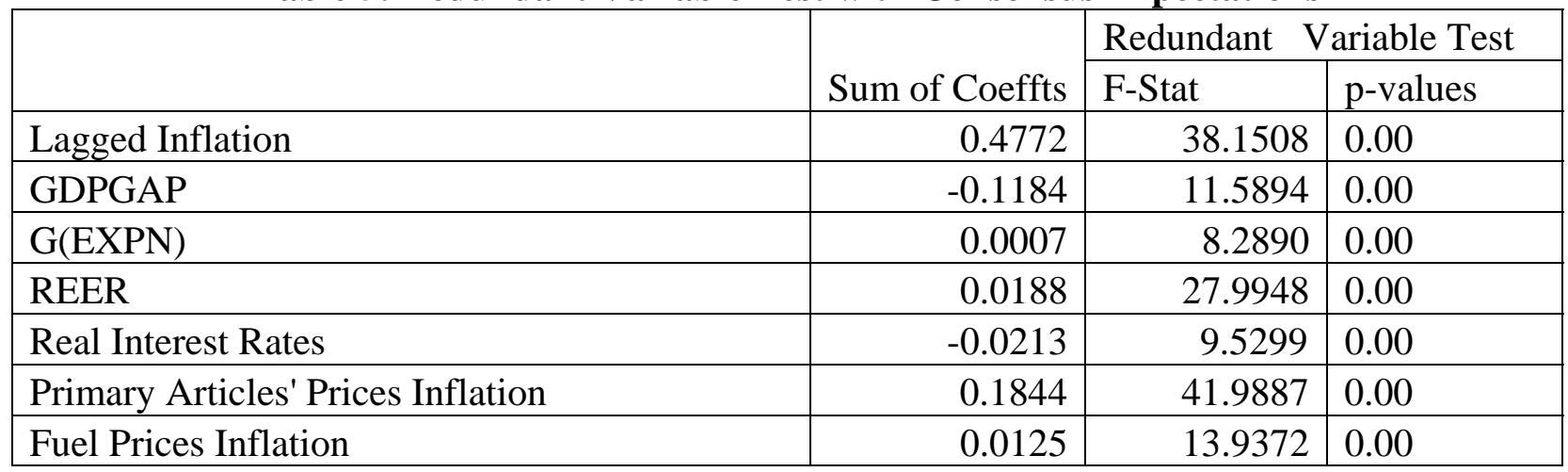

\footnotetext{
${ }^{6}$ Estimates using consensus expectations yield equally small but positive and significant coefficients.
} 


\section{Is it a Cointegrating Equation?}

Employing the Johannsen-Juselius procedure, we find that cointegrating vectors among the variables exist (AII) and that the preferred new-Keynesian Phillips curve specification is one of them. As a further corroboration, we test the residuals from the equation found in Table A1 by the Engle-Granger two-step procedure and find them to be white noise as shown below.

\begin{tabular}{|l|c|c|}
\hline \multicolumn{3}{|c|}{ Table 6: Results for Engle-Granger Procedure } \\
\\
(Null Hypothesis: Residuals from Equation of Table 4 has a unit root) \\
\hline \\
\hline
\end{tabular}

\section{Conclusion}

Back to the present and the classic dilemma facing policy authorities in India - to act against inflation and risk undermining the recovery, or accommodate the resumption of growth and risk inflationary pressures getting embedded in expectations. The empirical evidence presented in this paper indicates there is a considerable degree of inertia, relative to findings for other countries, in the formation of inflation expectations in India. To that extent, the current experience with high and climbing inflation in terms of primary articles and more so in terms of food prices could easily seep into people's anticipation of future inflation and linger. This needs to be seen in conjunction with the finding that a third of the variations in future inflation almost as much as past inflation - are explained by food prices contained in the index for prices for primary articles. Moreover, shocks delivered by food prices on the overall level of prices are relatively slow in reverting to mean. In our view, therefore, the argument that the current phase of inflationary pressures is essentially a supply-side phenomenon and monetary policy has little to do or can do little is overwhelmed by the clear and present danger of inflation expectations coming unhinged and taking on a lasting levitation. In India, monetary policy has traditionally been conducted in as manner that has anchored inflation perceptions and expectations around a threshold of 5 percent. This is particularly evident in financial markets' response to weekly announcements of the WPI. Indeed, in recent weeks beginning in late September 2009, the distinct ebbing of WPI inflation on a sustained basis confirmed market expectations that antiinflationary monetary policy action would be stayed, leading to yields on short-term instruments, including 91-day Treasury Bills, dipping below the RBI's interest rate corridor. The success gained in stabilizing inflation expectations, barring episodes at the end of 2006-07 and the first half of 2008-09 which were both externally induced, has emboldened the RBI to indicate within its medium-term striking range an inflation rate of 3 percent as consistent with India's integration into the global economy. There is thus a collateral and reputational bonus for monetary policy to be viewed as acting against inflation now in measured steps that indicate firm intent rather than going for cold turkey when the need to confront inflation cannot be held back any longer as societal compulsions reach a critical mass.

If the case for monetary policy action to anchor inflation expectations falls within the confidence limits of the decision-making process, the next issue is the way to go about it. The 
empirical findings of this paper show that the real interest rate has a significant effect on people's anticipations, outweighing the effects of fiscal policy or even exchange rate changes. Accordingly, the stock monetary policy response would need to be in terms of calibrated increases in policy rates, as mentioned earlier, with a readiness to stay ahead of the inflation curve so that real policy tightening is achieved. The RBI's January 2010 projection of endMarch 2010 WPI inflation is 8.5 percent, implying that a steep acceleration is underway. Other projections suggest that the RBI's forecast could turn out to be the base case and upside risks are high. The implications for prices of wholesale primary articles and consumer prices are ominous. Yet, increases in policy rates are likely to be ineffective in the current contrasting situation of abundant liquidity with absorptions through the RBI's absorption window averaging Rs 1.1 trillion daily, and more recent forces at work such as movements in cash balances of the Government, unwinding of sterilized funds sequestered with the RBI and expansion in the RBI's foreign currency assets (although reserve money movements suggest that accretions to foreign assets were largely sterilized). Consequently, the vanguard policy smoothing would need to be in terms of stepping up the exit from extraordinary liquidity provision facilities instituted at the height of the global crisis, followed up by more active liquidity drainage, including through aggressive use of reserve requirements. ${ }^{7}$ Given the experience worldwide, there is a growing case for distinguishing liquidity policy from monetary policy operations, the former taking the form of regular operations and the latter guided by the quarterly review cycle chosen by the RBI for its mainstream policy announcements.

Inflation expectations play a central role in setting and conducting monetary policy in modern times. Over a finite time horizon, inflation expectations reflect the credibility of the monetary authority's commitment to stated objectives. The effectiveness of monetary policy is likely to be greater if inflation expectations remain anchored. A sustained rise in expectations in the short-run runs the risk of heightened inflationary pressures in the medium-term. Hence, central banks have an incentive to understand how inflation expectations are formed. It is widely believed that imperfect information regarding central bank intentions has been one source of inertia in the formation of inflation expectations. This can be easily turned around. Imperfect knowledge of people's expectations can impart inertia to monetary policy responses. Thus, it is important to incorporate into the monetary policy process a good sense of what it is that people think. And that is where this paper began.

\footnotetext{
${ }^{7}$ In its review of monetary policy for the third quarter of 2009-10 (i.e., October - December, 2009), announced on January 29, 2010, the RBI raised the cash reserve ratio by 75 basis points but kept its key policy rates unchanged. On March 19, 2010 the RBI increased its key policy repo and reverse repo rates by 25 basis points each.
} 


\section{ANNEX I: DETERMINANTS OF INFLATION EXPECTATIONS}

\begin{tabular}{|c|c|c|c|c|}
\hline \multicolumn{5}{|c|}{ Table 7: Determinants of Inflationary Expectation (Model-based Forecasts) } \\
\hline Variable & Coefficient & Std. Error & t-Statistic & Prob. \\
\hline Constant & 0.009680 & 0.002842 & 3.406411 & 0.0011 \\
\hline Lagged Inflation(-1) & 0.467190 & 0.043458 & 10.75035 & 0.0000 \\
\hline Lagged Inflation (-11) & -0.347933 & 0.064165 & -5.422460 & 0.0000 \\
\hline Lagged Inflation (-12) & 0.341650 & 0.068878 & 4.960187 & 0.0000 \\
\hline GDPGAP(-1) & 0.138062 & 0.029408 & 4.694740 & 0.0000 \\
\hline G(EXPN)(-1) & -0.000253 & 0.000199 & -1.272781 & 0.2071 \\
\hline G(EXPN) (-4) & -0.000502 & 0.000200 & -2.507965 & 0.0143 \\
\hline $\mathrm{G}(\mathrm{EXPN})(-5)$ & -0.000679 & 0.000205 & -3.306937 & 0.0015 \\
\hline G(EXPN) (-8) & -0.000580 & 0.000196 & -2.958714 & 0.0041 \\
\hline G(REER)(-10) & -0.089328 & 0.024469 & -3.650673 & 0.0005 \\
\hline G(REER)(-11) & 0.060025 & 0.023426 & 2.562294 & 0.0124 \\
\hline Real Interest Rate(-1) & -0.011054 & 0.007776 & -1.421526 & 0.1594 \\
\hline Real Interest Rate (-2) & -0.012793 & 0.008050 & -1.589191 & 0.1163 \\
\hline Real Interest Rate (-4) & -0.012719 & 0.008247 & -1.542301 & 0.1273 \\
\hline Real Interest Rate (-9) & -0.007842 & 0.008158 & -0.961338 & 0.3395 \\
\hline Real Interest Rate (-12) & -0.016666 & 0.008233 & -2.024344 & 0.0465 \\
\hline$\pi^{\mathrm{PR}}$ & 0.174784 & 0.026323 & 6.639931 & 0.0000 \\
\hline$\pi^{\mathrm{PR}}(-12)$ & 0.115489 & 0.024187 & 4.774825 & 0.0000 \\
\hline$\pi^{\mathrm{FL}}$ & 0.068762 & 0.022961 & 2.994748 & 0.0037 \\
\hline$\pi^{\mathrm{FL}}(-1)$ & 0.088694 & 0.026505 & 3.346371 & 0.0013 \\
\hline$\pi^{\mathrm{FL}}(-12)$ & -0.051769 & 0.010271 & -5.040437 & 0.0000 \\
\hline R-squared & 0.977566 & \multicolumn{2}{|c|}{ Mean dependent var } & 0.054068 \\
\hline Adjusted R-squared & 0.971503 & \multicolumn{2}{|c|}{ S.D. dependent var } & 0.022268 \\
\hline S.E. of regression & 0.003759 & \multicolumn{2}{|c|}{ Akaike info criterion } & -8.136982 \\
\hline Sum squared resid & 0.001046 & \multicolumn{2}{|l|}{ Schwarz criterion } & -7.572441 \\
\hline Log likelihood & 407.5067 & \multicolumn{2}{|c|}{ Hannan-Quinn criter. } & -7.908865 \\
\hline F-statistic & 161.2296 & \multicolumn{2}{|c|}{ Durbin-Watson stat } & 1.859746 \\
\hline Prob(F-statistic) & 0.000000 & \multicolumn{2}{|c|}{ ARCH 1-6 test: 1.3248 [0.2597] } & \\
\hline AR 1-6 test: 1.0565 [0.33] & & \multicolumn{2}{|c|}{ Normality test: 9.0155 [0.0110] } & \\
\hline Hetero test: 0.50548 [0.9799] & & \multicolumn{2}{|c|}{ RESET test: 0.41338 [0.5223] } & \\
\hline
\end{tabular}




\begin{tabular}{|c|c|c|c|c|}
\hline \multicolumn{5}{|c|}{ Table 8: Determinants of Inflationary Expectation (based on Consensus Expectations) } \\
\hline Variable & Coefficient & Std. Error & t-Statistic & Prob. \\
\hline $\mathrm{C}$ & 0.017022 & 0.001845 & 9.225329 & 0.0000 \\
\hline Lagged Inflation(-1) & 0.347068 & 0.058696 & 5.912935 & 0.0000 \\
\hline Lagged Inflation (-7) & -0.090265 & 0.051328 & -1.758569 & 0.0845 \\
\hline Lagged Inflation (-12) & 0.203359 & 0.041968 & 4.845585 & 0.0000 \\
\hline GDPGAP & -0.017869 & 0.007247 & -2.465546 & 0.0170 \\
\hline GDPGAP(-6) & -0.126999 & 0.019108 & -6.646312 & 0.0000 \\
\hline GDPGAP(-7) & 0.125718 & 0.023346 & 5.384914 & 0.0000 \\
\hline GDPGAP(-9) & -0.142886 & 0.025860 & -5.525282 & 0.0000 \\
\hline GDPGAP(-10) & 0.115813 & 0.023874 & 4.850896 & 0.0000 \\
\hline GDPGAP(-12) & -0.072185 & 0.013173 & -5.479910 & 0.0000 \\
\hline $\mathrm{g}(\mathrm{EXPN})$ & -0.000107 & 5.42E-05 & -1.977921 & 0.0532 \\
\hline $\mathrm{g}(\mathrm{EXPN})(-1)$ & -0.000106 & 4.93E-05 & -2.157440 & 0.0356 \\
\hline $\mathrm{g}(\mathrm{EXPN})(-6)$ & 0.000206 & 4.32E-05 & 4.783180 & 0.0000 \\
\hline $\mathrm{g}(\mathrm{EXPN})(-7)$ & 0.000176 & $4.66 \mathrm{E}-05$ & 3.764838 & 0.0004 \\
\hline $\mathrm{g}(\mathrm{EXPN})(-9)$ & 0.000186 & $4.54 \mathrm{E}-05$ & 4.101182 & 0.0001 \\
\hline $\mathrm{g}(\mathrm{EXPN})(-10)$ & 0.000177 & 4.85E-05 & 3.647505 & 0.0006 \\
\hline g(EXPN) $(-11)$ & 0.000157 & 4.35E-05 & 3.620301 & 0.0007 \\
\hline g(REER) & -0.029892 & 0.005689 & -5.254570 & 0.0000 \\
\hline g(REER) (-1) & 0.019997 & 0.005664 & 3.530355 & 0.0009 \\
\hline $\mathrm{g}(\mathrm{REER})(-4)$ & -0.006000 & 0.003012 & -1.992264 & 0.0516 \\
\hline $\mathrm{g}(\mathrm{REER})(-10)$ & 0.013184 & 0.004391 & 3.002714 & 0.0041 \\
\hline g(REER) (-12) & 0.021522 & 0.004882 & 4.408700 & 0.0001 \\
\hline Real Interest Rate(-3) & 0.003338 & 0.001818 & 1.835895 & 0.0721 \\
\hline Real Interest Rate (-6) & -0.003868 & 0.001773 & -2.181444 & 0.0337 \\
\hline Real Interest Rate (-7) & 0.004173 & 0.001935 & 2.155953 & 0.0357 \\
\hline Real Interest Rate (-8) & -0.008026 & 0.001827 & -4.393624 & 0.0001 \\
\hline Real Interest Rate (-11) & -0.005933 & 0.001884 & -3.149495 & 0.0027 \\
\hline Real Interest Rate (-12) & -0.011026 & 0.002303 & -4.787435 & 0.0000 \\
\hline$\pi^{\mathrm{PR}}(-2)$ & 0.040585 & 0.006836 & 5.937223 & 0.0000 \\
\hline$\pi^{\mathrm{PR}}(-4)$ & 0.034070 & 0.009212 & 3.698537 & 0.0005 \\
\hline$\pi^{\mathrm{PR}}(-7)$ & 0.044695 & 0.008520 & 5.245788 & 0.0000 \\
\hline$\pi^{\mathrm{PR}}(-11)$ & 0.065006 & 0.009020 & 7.207241 & 0.0000 \\
\hline$\pi^{\mathrm{FL}}(-2)$ & 0.031461 & 0.005959 & 5.279978 & 0.0000 \\
\hline$\pi^{\mathrm{FL}}(-3)$ & -0.010559 & 0.005583 & -1.891478 & 0.0641 \\
\hline$\pi^{\mathrm{FL}}(-9)$ & -0.014964 & 0.003844 & -3.892462 & 0.0003 \\
\hline$\pi^{\mathrm{FL}}(-12)$ & 0.006605 & 0.003207 & 2.059457 & 0.0445 \\
\hline R-squared & 0.992581 & Mean dependent var & & 0.050639 \\
\hline Adjusted R-squared & 0.987160 & S.D. dependent var & & 0.006763 \\
\hline S.E. of regression & 0.000766 & Akaike info criterion & & -11.21239 \\
\hline Sum squared resid & $3.05 \mathrm{E}-05$ & Schwarz criterion & & -10.13631 \\
\hline Log likelihood & 549.1639 & Hannan-Quinn criter. & & -10.77826 \\
\hline F-statistic & 183.0916 & Durbin-Watson stat & & 2.602310 \\
\hline Prob(F-statistic) & 0.000000 & & & \\
\hline
\end{tabular}




\section{ANNEX II \\ COINTEGRATING VECTORS FOR INFLATION EXPECTATIONS AND DETERMINANTS}

List of variables included in the cointegrating vector: Inflation, GDP Gap, Real Expenditure Growth (Centre), Change in Real Effective Change Rate, Real Interest Rate, and Changes in Primary Articles Prices and Changes in Fuel Prices.

Table 9: Cointegration LR Test Based on Maximal Eigenvalue of the Stochastic Matrix

\begin{tabular}{|l|l|r|r|r|}
\hline Null & Alternative & Statistic & 95\% Critical Value & $\begin{array}{r}\text { 90\%Critical } \\
\text { Value }\end{array}$ \\
\hline $\mathrm{r}=0$ & $\mathrm{r}=1$ & 142.669 & 42.3 & 39.39 \\
\hline $\mathrm{r}<=1$ & $\mathrm{r}=2$ & 107.0166 & 36.27 & 33.48 \\
\hline $\mathrm{r}<=2$ & $\mathrm{r}=3$ & 34.7275 & 29.95 & 27.57 \\
\hline $\mathrm{r}<=3$ & $\mathrm{r}=4$ & 23.0125 & 23.92 & 21.58 \\
\hline $\mathrm{r}<=4$ & $\mathrm{r}=5$ & 14.8864 & 17.68 & 15.57 \\
\hline $\mathrm{r}<=5$ & $\mathrm{r}=6$ & 7.1997 & 11.03 & 9.28 \\
\hline $\mathrm{r}<=6$ & $\mathrm{r}=7$ & 0.098741 & 4.16 & 3.04 \\
\hline
\end{tabular}

Table 10: Cointegration LR Test Based on Trace of the Stochastic Matrix

\begin{tabular}{|l|l|r|r|r|}
\hline Null & & & & 90\%Critical \\
\hline $\mathrm{r}=0$ & Alternative & Statistic & 95\% Critical Value & Value \\
\hline $\mathrm{r}<=1$ & $\mathrm{r}>=1$ & 329.6105 & 110.1 & 105.44 \\
\hline $\mathrm{r}<=2$ & $\mathrm{r}>=2$ & 186.9415 & 83.18 & 78.47 \\
\hline $\mathrm{r}<=3$ & $\mathrm{r}>=3$ & 79.9249 & 59.33 & 55.42 \\
\hline $\mathrm{r}<=4$ & $\mathrm{r}>=4$ & 45.1973 & 39.81 & 36.69 \\
\hline $\mathrm{r}<=5$ & $\mathrm{r}>=5$ & 22.1849 & 24.05 & 21.46 \\
\hline $\mathrm{r}<=6$ & $\mathrm{r}>=6$ & 7.2985 & 12.36 & 10.25 \\
\hline
\end{tabular}

Note: Apart from two dummies for end of the year fiscal bunching and abnormal call money rate spike coinciding with limit placed by the RBI on Reverse Repo in March 2007, the conitegrating equation includes 11 centered dummies. 
Table 11: Estimated Cointegrated Vectors in Johansen Estimation (Normalized in Brackets)

\begin{tabular}{|l|r|r|r|}
\hline & Vector 1 & Vector 2 & Vector 3 \\
\hline Inflation & 14.1422 & 7.3138 & -13.7251 \\
\hline GDPGAP & $(-1.0000)$ & $(-1.0000)$ & $(-1.0000)$ \\
\hline & -0.2597 & -2.6466 & 11.302 \\
\hline g(LEXPN) & $(.018364)$ & $(0.36187)$ & $(0.82346)$ \\
\hline & -0.0050098 & 0.059423 & 0.073902 \\
\hline g(REER) & $(.3542 \mathrm{E}-3)$ & $(-.0081248)$ & $(0.0053845)$ \\
\hline & $(0.25451$ & -0.15829 & 1.4233 \\
\hline Interest Rate & $(-.017996)$ & $(0.021643)$ & $(0.1037)$ \\
\hline & 6.0158 & -1.6344 & -1.3396 \\
\hline$\pi^{\text {PR }}$ & $(-.42537)$ & $(0.22347)$ & $(-.097602)$ \\
\hline & -6.9023 & -4.9309 & 4.8468 \\
\hline$\pi^{\text {FL }}$ & $(.48807)$ & $(0.67419)$ & $(0.35313)$ \\
\hline & -3.9656 & -4.1982 & 2.0382 \\
\hline
\end{tabular}




\section{References}

Batchelor, R., and P. Dua, 1987, “The Accuracy and Rationality of UK Inflation Expectations,” Oxford Bulletin of Economics and Statistics, 48, pp 99-120.

Baum, Christopher F., Mark E. Schaffer and Steven Stillman, 2003, "Instrumental Variables and GMM: Estimation and Testing,” Working paper No. 545 (February), Department of Economics, Boston College, Massuchusetts, USA.

Blanchard, Olivier J, 1990, "Why Does Money Affect Output? A Survey", in Benjamin Friedman and Frank Hahn (eds): Handbook of Monetary Economics Vol. 2, Amsterdam: North Holland.

Blanchflower, David G., and Conall MacCoille, 2009, "the Formation of Inflation Expectations: An Empirical Analysis for the UK," National Bureau of Economic Research (NBER) Working Paper No. 15388 (Cambridge, Massachusetts).

Brissimis, Sophocles N., and Nicholas S. Magginas, 2008, "Inflation Forecasts and the New Keynesian Phillips Curve,” International Journal of Central Banking, Vol. 4 No. 2 (June), pp 1-21.

Campos, J. N.R. Ericsson and D.F. Hendry, 2004, General to Specific Modeling, Edward Elgar.

Callen, Tim, and Dongkoo Chang, 1999, “Modeling and Forecasting Inflation in India," IMF Working Paper, WP/99/119 (September), International Monetary Fund, Washington D.C.

Cerisola, M., and R. Gaston Gelos, 2005, "What Drives Inflation Expectations in Brazil? An Empirical Analysis” IMF Working Paper, WP/05/109 (June), International Monetary Fund, Washington D.C.

Celasun, O., R. Gaston Gelos, and Alessandro Prati, 2004a, “Obstacles to Disinflation: What is the Role of Fiscal Expectations?”, Economic Policy, Vol. 19 (October), pp 441-81

--------, 2004b, “Would 'Cold Turkey’ Work in Turkey?”, IMF Staff Papers, Vol. 51, No. 3, pp 493-509.

Chao, Hsiang-Ke, 2001, “Professor Hendry’s Econometric Methodology Reconsidered: Congruence and Structural Empiricism”, University of Amsterdam Working Paper.

Consensus Economics, various issues.

Gelos, G., and Fernanda Rossi Iriondo, 2008, “Inflation Process in Uruguay”, IMF Occasional Papers No. 263, pp 7-16.

Juntilla, Juha, 2001, "Structural Breaks, ARIMA Model and Finnish Inflation Forecasts," International Journal of Forecasting, No. 17, pp 203-230.

Kapur, M. and M. D. Patra, 2000, “The Price of Low Inflation”, Reserve Bank of India Occasional Papers, Volume 21, Nos.2 and 3, pp. 191-233.

Kiley, Michael T., 2009, "Inflation Expectations, Uncertainty, the Phillips Curve and Monetary Policy,” Finance and Economics Discussion Series, No. 2009-15, Federal Reserve Board, Washington D.C.

Krolzig, Hans-Martin and David Hendry, 1999: “Computer Automation of General-to-Specific Model Selection Procedures”, University of Oxford Working Paper.

Lucas, Robert E. Jr., 1972, “Expectations and the Neutrality of Money," Journal of Economic Theory 4(2), pp 103-124

Mankiw, N. Gregory, Ricardo Reis and Justin Wolfers, 2003, "Disagreement about Inflation Expectations,” NBER Working Paper No. 9796 (June), (Cambridge, Massachusetts).

McCallum, Bennett, 1997, "Comment on 'An Optimization-Based Econometric Framework for the Evaluation of Monetary Policy,” NBER Macroeconomics Annual 1997, pp 355-359 
McCulloch, J. Huston, and Jeffrey A. Stec, 2000, "Generating Serially Uncorrelated Forecasts of Inflation by Estimating the Order of Integration Directly," Paper presented at the 6th International Conference on Computing in Economics and Finance, Barcelona, (July)

Meylar, Aidan, Geoff Kenny and Terry Quinn, 1998, "Forecasting Irish Inflation Using ARIMA Models,” Munich Personal RePEs Archive (MPRA) Paper No 11359 (December).

Millet, Fabien Curto, 2007, "Inflation Exoectations, the Phillips Curve and Monetary Policy," Kiel Working Paper No. 1339 (June), Institut fur Weltwirtschaft an der Universitat, Kiel, Germany.

Minella, A., Paulo Springer de Freitas, Ilan Goldfajn, and Marcelo Kfoury Muinhos, 2003, "Inflation Targeting in Brazil: Constructing Credibility Under Exchange Rate Volatility," Journal of International Money and Finance, Vol. 22, pp 1015-40

Muth, John F., 1961, "Rational Expectations and the Theory of Price Movements," Econometrica 29(3), pp 315-335.

Pacquet, A., 1992, "Inflation Expectations and Rationality, Economic Letters 40, pp 303-308.

Reserve Bank of India, 2002, Report on Currency and Finance, 2000-01, Mumbai, India.

-Annual Policy Statements and Review of Monetary Policy, various issues , Macroeconomic and Monetary Developments, various issues

----------, 2009, Report of the Working Group on Surveys, RBI Bulletin (September).

Roberts, J. M., 1995, "New Keynesian Economics and the Phillips Curve,” Journal of Money, Credit and Banking 27 (4), pp 975-984.

Samuelson, Robert L., 2009, “Inflation, Deflation - or Both?”, Washington Post, June 8.

Stock, J., and Mark Watson, 2007, "Why has US Inflation Become Harder to Forecast?" Journal of Money, Credit and Banking, 39 (1), pp 3-33.

Subbarao, D., 2009a, "Impact of the Global Financial Crisis on India Collateral Damage and Response", Speech delivered at the Symposium on 'The Global Economic Crisis and Challenges for the Asian Economy in a Changing World', Institute for International Monetary Affairs, Tokyo, February 18.

----------------, 2009b, "India - Managing the Impact of the Global Financial Crisis", Speech delivered at the Confederation of Indian Industry's National Conference and Annual Session, New Delhi, March 26.

---------------, 2009c, “Emerging Market Concerns: An Indian Perspective,” Speech at the G-30 International Banking Seminar, (October 5), Istanbul, Turkey.

----------------, 2008a, "The Global Financial Turmoil and Challenges for the Indian Economy”, Speech at the Bankers' Club, Kolkata, India, December 10.

---------------, 2008b, "Mitigating Spillovers and Contagion Lessons from the Global Financial Crisis", Speech at the RBI-BIS Seminar on 'Mitigating Spillovers and Contagion - Lessons from the Global Financial Crisis', Hyderabad, India, December 4.

Taylor, John B., 1980, “Aggregate Dynamics and Staggered Contracts,” Journal of Political Economy 88(1), pp 1-23. 